\title{
Ethical Culture, Employee Intention to Stay and Employee Productivity in the Rivers State Civil Service
}

\author{
${ }^{1}$ Waribugo Sylva, ${ }^{2}$ Dan-Jumbo Comfort T. \\ ${ }^{1}$ Department of Management, University of Port Harcourt \\ ${ }^{2}$ Department of Hospitality Management and Tourism, University of Port Harcourt
}

\begin{tabular}{|c|c|}
\hline & ABSTRACT \\
\hline $\begin{array}{l}\text { DOI: } 10.18775 / \text { jibrm.1849-8558.2015.25.3001 } \\
\text { URL: } \underline{\text { http://dx.doi.org/10.18775/jibrm.1849- }} \\
\text { 8558.2015.25.3001 }\end{array}$ & $\begin{array}{l}\text { The study investigated the relationship between ethical culture and employee productivity in } \\
\text { the Rivers State Civil Service. Also, the moderating effect of intention to stay on the } \\
\text { relationship between the variables was examined. A sample of } 321 \text { was determined using } \\
\text { Krejcie and Morgan sample size table from a population of } 1905 \text { Civil Servants from five top } \\
\text { ministries in the Rivers State Civil Service. Data for the study was obtained through the } \\
\text { utilization of a self-administered and structured questionnaire. The Spearman's Rank Order }\end{array}$ \\
\hline $\begin{array}{l}\text { Keywords: } \\
\text { Ethical culture, Employee productivity, Intention } \\
\text { to stay. }\end{array}$ & $\begin{array}{l}\text { Correlation Coefficient was used in analyzing the data with the aid of the Statistical Package } \\
\text { for Social Sciences version } 21 \text {. The results indicated moderate and positive correlations among } \\
\text { the dimensions of ethical culture and employee productivity. Also, employee's intention to } \\
\text { stay slightly moderated the relationship between the two variables. However, the moderating } \\
\text { role was not significant enough to reject the null hypothesis. This means that positive ethical } \\
\text { culture enhances emplovee productivity in the Civil Service and hence should be encouraged. }\end{array}$ \\
\hline
\end{tabular}

\begin{abstract}
1. Introduction
Improving the level of employee productivity has always been a major concern for business managers and scholars. Referring to Hanaysha (2016), an increase in employee productivity leads to better organizational performance and competitiveness of the organization. Kien (2012) contend that employee productivity is an indispensable element for strengthening the level of firm's competitiveness, sustaining its standard of performance, achieving targeted goals, and attaining stakeholders' expectations. In recent times, employee productivity is the major concept in the civil service (Okereke \& Daniel, 2010).
\end{abstract}

With the increase in the publications of research articles on the concept of employee productivity and its importance to the organization, the concept is gradually becoming the mainstay of discussion in every management and behavioral scientists' gatherings (Balachandran \& Thomas, 2007).

There is a rapid growth of awareness by scholars and experts in the field of development and adoption of ethical culture by enterprises. However, the search light has beamed more on private enterprises (Olaru \& Gurgu, 2009). The benefits of adopting ethical culture are greater than the cost attached to it. For instance, in the private sector, organizations with good ethical culture are perceived to be reputable, community friendly and demonstrate good corporate image. Ethical culture also helps to increase market share, employee commitment, loyalty, and stakeholder's trusts (Pirožek \& Drášilová, 2012). That is, ethical behavior helps businesses preserve a convincing reputation in its operating market, strengthen the level of employee allegiance and identification with the firm. It also helps in contract discussions and negotiations between firms and its partners. All these lead to the achievement of competitive advantage by the organization (Olaru \& Gurgu, 2009).

Despite the key role of the public service in the economic well being of the country and its citizens, its work force has continued to perform dismally when compared to the private sector of the economy to the dismay of the government and at the detriment of tax payers. Agwu (2013) mentioned that this may be as a result of unethical behavior which states "a civil service with ill-defined or negative culture is usually a breeding ground for corruption, indolence, nepotism, inefficiency, lack of accountability/transparency, low productivity, misappropriation and waste of public funds". Adamade (2009) noted that due to the poor performance of the public sector in the country, the government has tried to revamp and reposition the sector to no avail.

Apparently, there are several scholarly works on ethical culture and employee productivity (e.g. Uddin, Luva, \& Hossian, 2013; Adeyeye, Adeniji, Osinbanjo, \& Oludayo, 2015). However, these studies mostly concentrated on private business settings to the detriment of public service organizations exemplified in government ministries and parastatals (Okereke \& Daniel, 2010). 
Therefore, the need to stretch frontiers of knowledge about the abovementioned concepts in the public sector is essential. It could be done by investigating the relationship between ethical culture and employee productivity using Rivers State Civil Service. Consequently, the mediating effect of intention to stay would be investigated.

\section{Literature review}

\subsection{Ethics, Business Ethics, and Ethical Culture}

Like most concepts in the social and management sciences, ethics has been defined in various ways by theoreticians. The provision of an accurate and generally acceptable definition is a major concern for ethics theorists. Beauchamp and Bowie (2001) define ethics as "the inquiry into theories of what is good and evil and into what is right and wrong, and thus is an inquiry into what we ought and ought not to do". Runes (1964) opined that ethical behavior involves parties maintaining the acceptable standards of behavior in their interactions. A similar definition was postulated by Barry (1979) who defines the study of ethics as the learning of what "constitutes good and bad human conduct, including related actions and values". Wu (1999) asserts that ethics is "the code of moral principles that set the standard of good or bad, or right or wrong behavior".

On the other hand, business ethics is the application of the right and acceptable conduct in the business arena (Monshipouri, Welch \& Kennedy, 2003). Business ethics is concerned with the study of organizational situations, their activities, and how decisions are made to address the issues of right or wrong in the organization, or between the organization and its stakeholders. According to Nwachukwu (2006), ethics is the "science of conduct" which involves studying what is right or wrong and accepting to do the right things. Thus, the study of what is right or wrong in the organization is referred to as ethics. Nwachukwu (2006) further define business ethics as realizing the right and wrong in the system and carrying out the right things. Therefore, business ethics is the formulation of policies and development of adoption of adequate principles. MOreover, it is values which can serve as the day-to-day guidelines for staff and management in taking decisions pertaining to what is morally right or wrong.

Stark (1993) defines business ethics as the study that has to do with the application of the right judgment to business activities. Anand and Rosen (2008) see it as "a form of applied ethics or professional ethics that examines ethical principles and moral or ethical problems that arise in a business environment". Ethics is applicable to all facets of business activities and is significant to the behavior of individuals and the organization as a group.

In their study, Arnold and Norman (2003) opine that business ethics is the etiquette that organizations maintain in its daily operations and exchange relationships with the outside world. Other authors have argued that ethics is diverse, and also applicable to the management of business interactions with individual customers. Capaldi (2006) avowed several businesses have damaged their reputation by just being in business. This contradicts the school of thought that "business of business is business" (Friedman, 1970). That is, the primary and only motive of business is to make a profit, which reflects the capitalist principles. Capaldi (2006) submits that "a business making money is not wrong but the manner and nature at which this money is made becomes a concern for scholars in the field of business ethics".

According to Dolan, Garcia, and Richley (2006), ethics is the science that relates to moral inclinations and a person's values and norms. Business ethics has to do with the intent and attitudes that would benefit the individual. Similarly, Ten and Willmott (2001) define business ethics as "the critical, structured examination of how people and institutions should behave in the world of commerce. In particular, it involves examining appropriate constraints on the pursuit of self-interest or profits, when the actions of individuals or firms affect others".

From the various definitions above, it can be deduced that business ethics simply means applying the concept of ethics in business. Business ethics can, therefore, be defined as a set of moral principles that determine how individuals and organizations should behave in the world of commerce.

\subsection{Theories of Business Ethics}

There are several theories that have been used in literature to explain the concept of ethics in business. Those theories are reviewed in current research which demonstrates great alignment with the reality in Nigeria: i. Shareholder theory

ii. Stakeholder theories

iii. Systems theory

\subsubsection{Shareholder Theory}

The shareholders' theory or view is also referred as classical theory (Karake, 1998) or fundamentalist theory (Curran, 2005). The theory maintains that every business should be managed in the best interests of the firm's shareholders, which is making a profit (Brenner \& Cochran, 1991). The theory states that a person is acting ethically if only the maximization of profit of its shareholders is assured.

As submitted by Greenwood (2001) the intention of every business is to make a profit and to give a higher return on investment to its shareholders. Therefore, businesses should be seen as a center for the creation of economic value for the risk takers (shareholders) of the enterprise. This is in conformity with the submissions of Friedman (1970), who states that "business of business is business".

Nilsson and Westerberg (1997) submit that so many benefits accrued from the shareholder's theory. The chief is the maximization of production. They believe that, when organizations concentrate on the generation and improvement of revenue, the end result would increase the productivity through the effective and efficient use of scarce production resources. This process leads to the minimization of waste and leakages. However, the main problem with this theory lies in the fact that, it does not give consideration to other stakeholders such as; suppliers, customers, employees, the environment. This could hurt and force other stakeholders to revolt. Ikpefan and Ayeni (2012) assert that "if a business decides to maximize profits, randomly fire employees, sell defective products to customers, and pollute the environment, they might still be considered ethically good as long as resources are being used efficiently. If they are committing 'off- balance-sheet' transactions that are considered within the realms of the law in order to maximize profit, then they might seem ethical under shareholder theory".

\subsubsection{Stakeholder Theory}

The stakeholder theory emerged as a direct substitute for the shareholder's theory. The theory clearly recognized the fact that it is not only the shareholders that sacrifices for the firm's success, but numerous set of stakeholders such as customers, host communities, employees and so on. Therefore, all the stakeholders must be considered when investment decisions are taken (Donaldson \& Preston, 1995; Spence, Coles \& Harris, 2001; Windsor, 2001). Thus, the organization has the 
obligation and responsibility to protect the interests of all the stakeholders no matter the nature of their contribution to the firm.

Stakeholder theory makes efforts to address the question of what purposes businesses are supposed to serve and in whose interest it should be run (Jelena, 2007). The origin of this theory is traced to R.E. Freeman (1984), he postulated it as an alternative to the general belief, that shareholders are superior to other stakeholders of firms. Though, Freeman pointed out that the principles and idea in which stakeholder theory is driven existed before his origination of the concept. Podar and Jancic (2006) stated that "within the stakeholder theory framework, companies are seen to be involved in the social system and forced to enter into a new social contract. This new social contract presents a mix of reciprocal expectations of the role and responsibilities of each involved parties in a corporate and social environment".

The underlying principle of the Stakeholder Theory is based on the premises that require high-level performance. Business management in its turn must pay serious attention to virtually all its numerous stakeholders. Secondly, managers are answerable to stakeholders to the extend beyond the purview of shareholders (Jones \& Wicks, 1999). The theory maintained that firms should not only make profits but must fulfill other responsibilities.

\subsubsection{Systems Theory}

The system theory is similar to the stakeholder theory of firm ethics. As an organizational theory, systems theory makes attempt at relating business to ethics (Nilsson \& Westerberg, 1997). As submitted by the systems theorists, solving social problems is not achievable without consideration of external factors. Preferably, social phenomena should be studied in the context of a system, since the individual components act as sub-systems and interact with other sub-systems within a larger system. According to Ackoff (1974), ethical behavior should involve the stakeholders in the decision-making process because of the outcomes of have the immense effect on them.

In a study on the adoption of ethical behavior by Nigerian banks, Ikpefan and Ayeni (2012) submit that the actions of any component of the system could have either positive or negative consequence on the remaining parts of the system. They, therefore, concluded that, despite the fact the ultimate goal of businesses is to enhance shareholders wealth through an increase of profitability, a cautious effort has to be made to always remain fair to other stakeholders of the firms. As such, one can say that the system theory focuses on "maintaining the equilibrium of the overall system and that subsystem interests are subordinate to the overall system interests" (Ikpefan \& Ayeni, 2012).

\subsection{Ethical Culture}

Ethical culture is the cautious act of implementing and adopting policies that are generally acceptable as right by the majority of the stakeholders of the firm. Truxillo, Bauer and Erdogan (2016) succinctly put it that "having an organizational culture that emphasizes ethical behavior can cut down on misbehavior of organizations", they concluded that "whether an organization develops a culture that emphasizes doing the right thing even when it is costly comes down to whether leaders, starting with the $\mathrm{CEO}$, consider the ethical consequences of their actions. Leaders with a moral compass set the tone when it comes to ethical dilemmas". Treviño and Weaver (2003) define ethical culture as those behaviors that encourage ethical deeds in firms.
Tozer (2012) outlines the consequences operating in an unethical, irresponsible, unprincipled, unconscionable and nefarious manner to include the loss of customers' support, lack of trust by suppliers, negative reputable and damage of company's image. Nguyen (2017) added that the firm will not only lose customer, suppliers, and community trust but will also lose the support of its workers and managers.

Therefore, ethical culture is concerned with managers and employees alike conforming to the organization's ethical code of conductorganization. That is, how the firm responds to the internal or external stimulus without breaching the code of conduct.

Ethical culture is dimensionalized using clarity, supportability, transparency and sanctionability, all adopted from Kaptein (2007). Clarity has to do with stating concrete, comprehensive and understandable expectations from the employees. Supportability lies in creating an ambient environment which adequately supports or helps employees achieve expectations within ethical boundaries. However, transparency talks about the extent to which the organization has made the workers understand the repercussions of their actions and inactions. Lastly, the sanctionability dimension is a concern of employees' knowledge about ethical or unethical behavior which would be rewarded or punished.

\subsection{Employee Productivity}

Employee productivity is one of the emerging concepts in management literature and it is one of the foremost challenges confronting organizations (Hanaysha, 2016). The increasing interest in this concept might be related to the fact that, organizational success significantly rely on the productivity level of its work force (Kawara, 2014). However, productivity itself is of immense concern for almost all organizations and managers, therefore, must be taken seriously.

Productivity has been described in so many ways by numerous scholars. For example, Sultana, Irum, Ahmed and Mehmood (2012) define productivity as the capability to accomplish stated objectives within a definite time frame at a determined cost and an acceptable standard. In other words, since the goal of every organization is to achieve maximum output, therefore productivity must be given special attention.

Various definitions of employee productivity have been proposed by contemporary management scholars, amongst which include, Ferreira and Du Plessis (2009) who define employee productivity as "the time spent by an employee in executing his or her job duties, in order to achieve expected outcomes based on the job description". Likewise, Mathis and Jackson (2000) describe employee productivity as "the quantity and quality of work done by an employee taking into consideration the costs of resources being used to achieve that work". Therefore, enhancing workers productivity is not only an important objective of organizations but the whole essence of management. Thus, improvement of employee output results to higher organizational performance (Brown, 2012; Hanaysha, 2016). Also, Kien (2012) concluded that "increasing employee's productivity can lead to favorable outcomes such as: competitive advantage, maintaining strategic and financial results, achieving organizational goals, and fulfilling stakeholders' value propositions"

\subsection{Ethical Culture and Employee Productivity}

There are scanty empirical studies examining the correlation between these two variables (e.g., Patterson, War \& West, 2004; Pattison \& Edgar, 2011). Patterson, War and West (2004) examine the influence of 
company climate on its productivity using 42 production firms and found a significant relationship between the two variables. They further established that ethical organizational culture leads to higher productivity and results in higher employee satisfaction. Pattison and Edgar (2011) focused on integrity and moral disposition of practicing nurses and how it affects the productivity of nurses.

Studies have revealed that ethical culture positively correlates with employee work performance. Other forms of ethical culture, such as ethical leadership have been shown to positively correlate with employee work outcomes (e.g. Uddin, 2012; Adeyeye, Adeniji, Osinbanjo, \& Oludayo, 2015)

\subsection{Ethical Culture, Employee Productivity and Intention to Stay}

Several scholars have examined the interrelationship between ethical culture and organizational outcomes, including employee productivity. For example, Brown and Trevino (2006) investigated the ethical leadership as a component of ethical culture to employee work attitudes and behavior. He concluded that unethical leadership affects productivity negatively. O'Fallon and Butterfield (2005) state that ethical culture is a topic of growing research interest, necessitating employee intentions. There are several other studies linking ethical culture measures to a variety of employee outcomes which include employee productivity (Pettijohn, Pettijohn, \& Taylor, 2008; Valentine, Godkin, Fleischman, \& Kidwell, 2011).

Though there is a scarcity of empirical research investigating the effect of employee intention on the relationship between ethical organizational culture and employee productivity. Pettijohn, Pettijohn, and Taylor (2008) investigated the influence of turnover intentions on the perceptions of ethical behaviors of salespersons. They concluded that employee turnover intentions could negatively affect their perception of ethical culture. Similarly, Valentine, et al. (2011) died "Corporate ethical values, group creativity, job satisfaction and turnover intention", and submit that turnover intention slightly moderate the relationship between corporate ethical culture and the other variables.

The conceptual framework in fig. 1 below was developed as a guide for this study. The framework shows the relationships between ethical culture and employee productivity (hypothesis 1), and the moderating effect of employee intention to stay on the relationship between ethical culture and employee productivity (hypothesis 2).

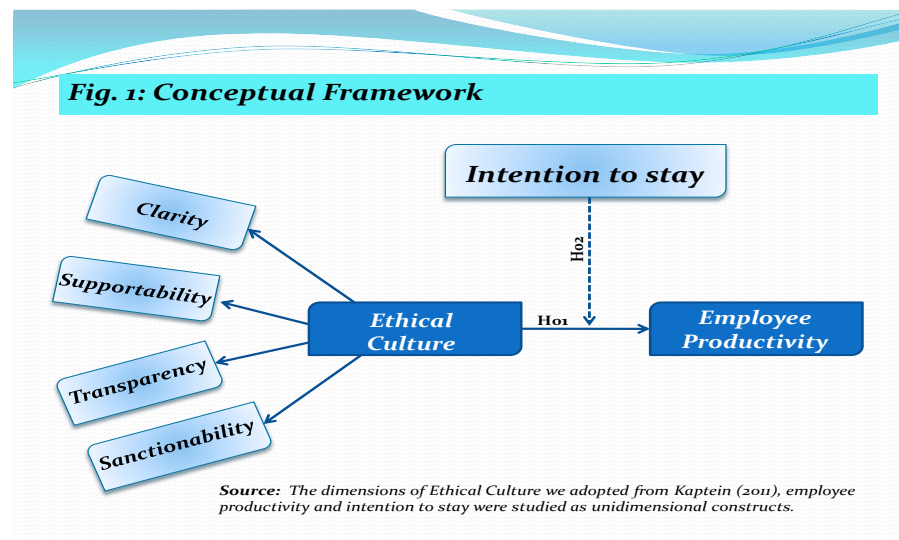

Research Hypotheses

i. There is no significant relationship between the dimensions of ethical culture and employee productivity. ii. Intention to stay does not significantly moderate the relationship between ethical culture and employee productivity.

\section{Methodology \\ 3.1 Research Design}

In this study, the cross-sectional survey, a type of quasi-experimental research design, was adopted. The reason for the choice of this method is that the study is concerned with the investigation of the relationship between the dependent and independent variables (Creswell, 2009). Also, data for the study were collected at a single point in time using a structured research instrument (Tharenou, Donohue \& Cooper, 2007).

The population for this comprises civil servants in the Rivers State Civil Service. There are a total of 55 parastatals in the Rivers State Civil Service, comprising 26 ministries, 25 agencies and 4 commissions (Civil Service Commission, 2017). However, for easy accessibility, 5 of these ministries which could be classified as super-ministries with the highest number of employees were chosen for these studies. They are ministries of agriculture, 566 employees, education 425, power 372, transport 291, and environment 251, making a population of 1905 employees. The Krejcie and Morgan (1970) sample size determination table was used to determine a sample size of 321 .

\subsection{Questionnaire Design}

In order to generate data from the respondents, a research instrument comprising two parts (A \& B) was developed. Part A of the instrument has questions eliciting answers on the demographic details of the respondents. It has statement items such as age, gender, and position in the organization. Part B is concerned with the variables under investigation (ethical culture, employee productivity, and intention to stay). The items under section B were anchored on a five-point Likert scale at both ends such that $5=$ strongly agree and $1=$ strongly disagree.

\subsection{Operational Measures of Variables}

The independent variable (ethical culture) was dimensionalized using clarity, supportability, transparency, and sanctionability. A total of 32 statement items were used to measure the independent variable. Clarity dimension has 10 items (e.g. "my ministry makes it sufficiently clear to me how I should conduct myself appropriately toward others within the work environment; My ministry makes it sufficiently clear to me how I should handle money and other financial assets responsibly"). Supportability has 6 statement items (e.g. "In my immediate working environment, everyone has the best interests of the ministry at heart; In my immediate working environment, an atmosphere of mutual trust prevails"). Transparency was measured using 7 items (e.g. "If a colleague does something which is not permitted, I or another colleague will find out about it; In my immediate working environment, there is adequate awareness of potential violations and incidents in the organization"). Lastly, sanctionability has 9 items (e.g. "In my immediate working environment, people are accountable for their actions; In my immediate working environment, employees will be disciplined if they behave unethically"). All the items were adapted from Kaptein (2008).

The dependent variable (employee productivity) was studied as a unidimensional construct, using 5 statement items to describe it (e.g. "I accomplish tasks quickly and efficiently; I always beat our team targets"). The items were adapted from the work of Hanaysha (2016). Similarly, the moderating variable (intention to stay) was measured using 4 items adapted from Kumar and Santhosh (2014) with statement items such as 
"I see myself working for this ministry three years from; Even if I had another job offer that higher pay, I rather stay here".

\subsection{Reliability and Validity of the Instrument}

The instrument reliability was determined through the computation of the Cronbach's alpha values. The items describing the dimensions of ethical culture (clarity, supportability, transparency, and sanctionability) showed alpha values of $0.88,0.78,0.84$ and 0.87 respectively. Whereas the items of employee productivity returned value of 0.86 , employee intention to stay returned 0.72 respectively. All the Cronbach alpha values are above the 0.7 acceptable yardsticks suggested by Nunnaly and Bernstein (1994) and supported by Sekaran (2000). Therefore, the instrument items were considered reliable and suitable for analysis in this study.

The scales used in this study were sourced from a rigorous literature review process, which helps to ensure content validity of the instrument (Polit, \& Beck, 2006; Patrick, et al., 2011). Similarly, a sample of the instrument was given to organizational experts as well as a selected number of senior and management staff of the ministries for the observations. Their input led to the adjustment in some of the items to suit the Nigerian working environment. This step justified the face validity of the instrument (Hayton, Allen, \& Scarpello, 2004; Polit, Beck, \& Owen, 2007). In addition, construct and content validity of the items have severally been confirmed in previous studies and in studies where they were adapted.

\section{Data Analysis and Discussion}

In order to test the first hypothesis, the Spearman's Rank Order Correlation Coefficient was used to analyze the correlations between the dimensions of ethical culture (clarity, supportability, transparency, and sanctionability) and employee productivity. The Spearman's Rank Order Correlation Coefficient (rho) was suitable for these analyses because the data generated from the items were quantitative, ordinal and not normally distributed. Also, the intent was to find the level of relationship between two variables (Gravetter \& Wallnau, 2000; Tabachnick \& Fidell, 2001). To test the mediating effect of intention to stay on the relationship between ethical culture and employee productivity, partial correlation technique was used to analyze the data.

A total of 321 Copies of the structured questionnaire was distributed randomly to civil servants in the five ministries. 246 copies of the questionnaire were returned representing a $77 \%$ response. However, after data cleaning 24 copies were not useable due to conflicting information and/or incomplete information. The remaining 222 copies were used for the analysis. The correctly filled and usable copies (222) represented 69\% of the total number of the questionnaire distributed and sufficient for a valid conclusion (Nutty, 2008; Fincham, 2008).

\subsection{Hypotheses Testing}

Hypothesis 1 (H01): The first hypothesis states that there is no significant relationship between the dimensions of ethical culture (clarity, supportability, transparency, and sanctionability) and employee productivity. The table 1 shows the outcome of the analysis.

Correlation is significant at the 0.05 level (2-tailed). **

Predictors: (Constant), Clarity, Supportability, Transparency, and Sanctionability.

Dependent Variable: Employee Productivity
Table 1: Correlations between the dimensions of ethical culture and employee productivity

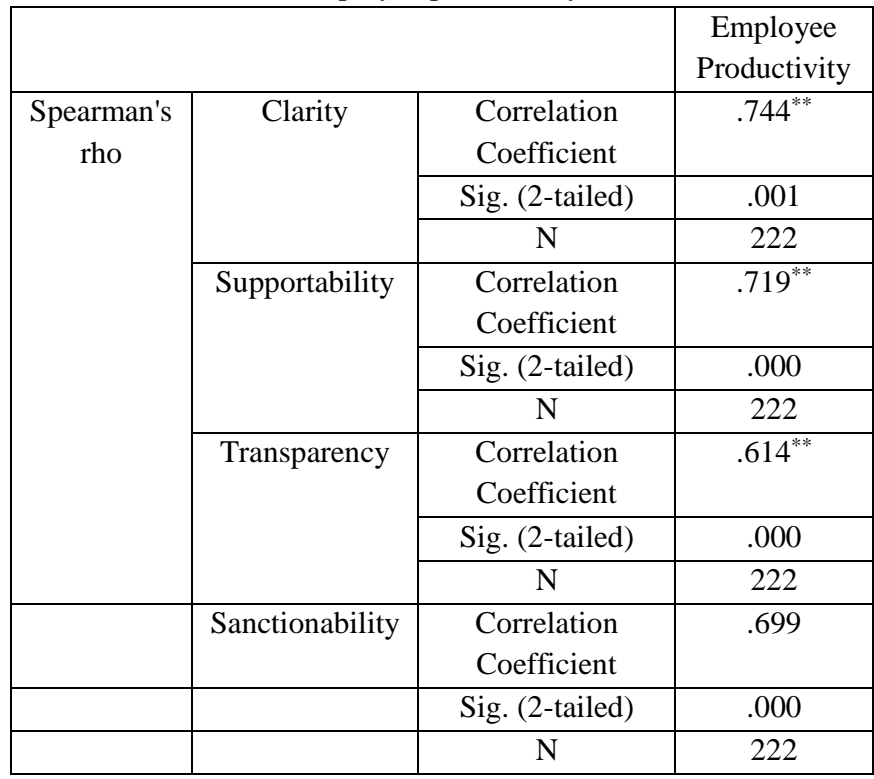

Table 2: Ethical Culture, Intention to stay and employee productivity

\begin{tabular}{|c|c|c|c|c|c|}
\hline \multicolumn{3}{|c|}{ Control Variables } & \multirow{2}{*}{$\begin{array}{l}\begin{array}{l}\text { Ethical } \\
\text { Culture }\end{array} \\
1.000\end{array}$} & \multirow{2}{*}{$\begin{array}{l}\text { Employee } \\
\text { productivit } \\
\text { y } \\
.694\end{array}$} & \multirow{2}{*}{$\begin{array}{l}\text { Intent } \\
\text { ion to } \\
\text { stay } \\
.589\end{array}$} \\
\hline \multirow{9}{*}{$\begin{array}{l}- \\
\text { none- } \\
\text { a }\end{array}$} & \multirow{3}{*}{$\begin{array}{l}\text { Ethical } \\
\text { culture }\end{array}$} & Correlation & & & \\
\hline & & $\begin{array}{l}\text { Significanc } \\
\text { e (2-tailed) }\end{array}$ & . & .000 & .001 \\
\hline & & Df & 0 & 222 & 219 \\
\hline & \multirow{3}{*}{$\begin{array}{l}\text { Emplo } \\
\text { yee } \\
\text { Product } \\
\text { ivity }\end{array}$} & Correlation & .694 & 1.000 & .613 \\
\hline & & $\begin{array}{l}\text { Significanc } \\
\text { e (2-tailed) }\end{array}$ & .000 & . & .000 \\
\hline & & Df & 222 & 0 & 219 \\
\hline & \multirow{3}{*}{$\begin{array}{l}\text { Intentio } \\
\mathrm{n} \text { to } \\
\text { stay }\end{array}$} & Correlation & .589 & .613 & 1.000 \\
\hline & & $\begin{array}{l}\text { Significanc } \\
\text { e (2-tailed) }\end{array}$ & .001 & .000 & . \\
\hline & & Df & 219 & 219 & 0 \\
\hline \multirow{6}{*}{$\begin{array}{l}\text { Inten } \\
\text { tion } \\
\text { to } \\
\text { stay }\end{array}$} & \multirow{3}{*}{$\begin{array}{l}\text { Ethical } \\
\text { culture }\end{array}$} & Correlation & 1.000 & .713 & \\
\hline & & $\begin{array}{l}\text { Significanc } \\
\text { e (2-tailed) }\end{array}$ & . & .001 & \\
\hline & & Df & 0 & 219 & \\
\hline & \multirow{3}{*}{$\begin{array}{l}\text { Emplo } \\
\text { yees' } \\
\text { Commi } \\
\text { tment }\end{array}$} & Correlation & .713 & 1.000 & \\
\hline & & $\begin{array}{l}\text { Significanc } \\
\text { e (2-tailed) }\end{array}$ & .001 & . & \\
\hline & & Df & 219 & 0 & \\
\hline
\end{tabular}

The analyses reveal that all the dimensions of ethical culture are significantly and positively correlated with employee productivity with clarity and employee productivity having the highest rho of .744, $\mathrm{p}<0.05$, it was followed by supportability rho $=.719, \mathrm{p}<0.05$, sanctionability rho $=.699, \mathrm{p}<0.05$, and transparency rho $=.614, \mathrm{p}<0.05$. Therefore, the stated hypothesis that there is no significant relationship between the ethical culture and employee productivity was rejected. Thus, the alternative hypothesis was accepted.

Hypothesis 2 (H02): This hypothesis stated that employee intention to stay does not moderate the relationship between ethical culture and employee productivity. The result is as shown in the table 2 . 
The analysis shows that without considering the effect of employee intention to stay, there was a moderate correlation between ethical culture and employee productivity ( $r$ ho $=.694, \mathrm{n}=222$ and $\mathrm{p}<.05$ ). Whereas an observation of the relationship with the moderating effect of intention to stay reveals rho of .713 meaning that controlling for intention to stay had a positive but insignificant effect (0.019) on the strength of the relationship between ethical culture and employee productivity. Therefore, the null hypothesis that intention to stay does not significantly moderate the relationship between ethical culture and employee productivity was accepted.

\subsection{Discussion}

The findings in table one reveal that ethical culture positively and significantly affects employee productivity in the Rivers State Civil. This could be as a result of knowing the consequences of not doing work by employees. It is done with a purpose of carrying their function in a transparent environment and also knowing that they stand a chance of being sanctioned if fail to do their work. They are forced to put in their best ability to the realization of any given goal and maintain decorum. All these may lead to better output for the ministries and the achievement of targeted goals and objectives.

These findings are consistent with several studies (e.g. Patterson, War \& West, 2004; Uddin, 2012; Adeyeye, et al., 2015). Patterson, War and West (2004) established that organizational productivity is positively related to the ethical culture which leads to higher levels of employee job satisfaction. Similarly, Adeyeye, et al. (2015) in their study on the "effects of workplace ethics on employees and organizational productivity in Nigeria", concluded that ethical climate in the organization influences the way employees to do their work and the total level of output. Also, the finding that intention to stay does not significantly influence the relationship between ethical culture and employee productivity is in consonance with the findings of Pettijohn, Pettijohn and Taylor (2008) who in their study on "ethical behaviours: Their influence on job satisfaction and turnover intentions", submit that employee intentions relatively influence their ethical behaviour which in turn influence their outcomes such as satisfaction, and productivity. In a more recent study, Valentine, et al. (2011) investigated the relationship between "corporate ethical values, group creativity, job satisfaction and turnover intention" and came up with a similar result.

\section{Conclusion and Recommendations \\ 5.1 Conclusion}

The study focused on the relationship between ethical culture and employee productivity in the Rivers State Civil Service. Also, the moderating intention to stay was examined. It was found that all the dimensions of ethical culture significantly correlate with employee productivity, and intention to stay had a positive but inconsequential influence on the relationship between the two variables. Based on the result it is concluded that:

i. Clarity dimension of ethical culture positively and significantly influences employee productivity in the Civil Service.

ii. Supportability significantly affects the productivity of Civil Servants in the State.

iii. Transparency dimension affects employee productivity positively. iv. Transparency influences the level of employee productivity in the service.

v. Employee intention to stay enhances ethical behavior which in turn leads to greater levels of productivity in the civil service.

\subsection{Recommendations}

Based on the analysis, interpretations, and conclusion above, the following recommendations are put forward for adoption by the State Civil Service Commission:

i. There should be a clear and understandable ethical code of conduct for all employees. This should be made available to all employees for them to know what they are expected to do at all time and situations.

ii. The Civil Service Commission and individual ministries should set mechanisms to support employees to adhere to service norms, values, and standards seriously, which will, in turn, enhance their productivity.

iii. Consequences of unethical behaviors should be made known to employees, so as to deter unethical behaviors among them. This will lead to increase in their level of productivity.

iv. Disciplinary actions should be taken when employees get involved in unethical behaviors, while ethical behaviors should be rewarded to encourage employees to put in their best on the job.

\section{References}

- Adamade, S. S. (2009). Quality of work life, working conditions and public servants' performance in Nigeria. Nigeria Journal of Labour Law Review, 3(4), 43-59.

- Adeyeye, J.O, Adeniji, A. A., Osinbanjo, A.O., Oludayo, O.A. (2015). Effects of workplace ethics on employees and organisational productivity in Nigeria. International Conference on African Development Issues (CU-ICADI) 2015: Social and Economic Models for Development Track.

- Agwu, M. O. (2013). Organizational Culture and Employees Commitment in Bayelsa State Civil Service. Journal of Management Policies and Practices, 1(1), 35-45.

- Anand, V. \& Rosen, C. C. (2008). the ethics of organizational secrets. Journal of Management Inquiry, 17(2), 97-101. Crossref

- Arnold, D. G. \& Norman, E. B. (2003). Sweatshops and respect for persons. Business Ethics Quarterly, 13 (2), 221-242. Crossref

- Barry, V. (1979). Moral Issues in Business. New York: Wadsworth Publishing Co.

- Beauchamp, T. L., \& Bowie, N. E. (2001): Ethical theory and business (6th ed.). New Jersey: Upper Saddle River, Prentice Hall.

- Capaldi, N. (2006). What philosophy can and cannot contribute to business ethics. Journal of Private Enterprise, 22 (2), 68-86.

- Fincham, J. E. (2008). Response rates and responsiveness for surveys, standards, and the Journal. American Journal Pharmaceutical Education, 72 (2), 1-3. Crossref

- Freeman, R. E. (1984). Strategic management: A stakeholder approach. Boston: Pitman.

- Friedman, M. (1970). The social responsibility of business is to increase its profits. New York: New York Times.

- Gravetter, F. J., \& Wallnau, L. B. (2000). Statistics for the behavioral sciences (5th edn). Belmont, CA: Wadsworth.

- Greenwood, M. R. (2001). The community as the stakeholder: Focusing on corporate, social and environmental reporting. Journal of Corporate Citizenship, 4, 31-45. Crossref

- Hanaysha, J. (2016). Testing the effects of employee empowerment, teamwork, and employee training on employee productivity in higher education sector. International Journal of Learning \& Development, 6(1), 164-178.

- Hayton, J. C., Allen, D. G., \& Scarpello, V. (2004). Factor retention decisions in exploratory factor analysis: A tutorial on parallel analysis. Organizational research methods, 7(2), 191-205. Crossref

- Ikpefan, O. A. \& Ayeni, O. (2012). The impact of ethics and professionalism in the banking industry. Unpublished. Retrieved on 
25/02/2017,

eprints.covenantuniversity.edu.ng/1319/1/ayeni\%20ethics.pdf.

- Jelena, B. (2007). Business ethics in banking. Journal Series: Economics and Organization. 4(2), 173 - 182.

- Jones, T. M. \& Wicks, A. C. (1999). Convergent stakeholder theory. Academy of Management Review, 24, 206-221.

- Kaptein, M. (2008). Developing and testing a measure of the ethical culture of organizations: The corporate ethical virtues model. Journal of Organizational Behavior, 29, 923-947. Crossref

- Karake, Z. A. (1998). An examination of the impact of organizational downsizing and discrimination activities on corporate social responsibility as measured by a company's reputation index. Management Decision, 36(3), 206-216 Crossref

- Kawara, P. (2014). Effects of reward systems on employee productivity in Catholic University of Eastern Africa. International Journal of Recent Research in Commerce Economics and Management, 1(2), 1-4.

- Kien, B. T. (2012). Factors affecting the fluctuation of labor productivity in the construction projects. (Master Thesis, University of Economics), Ho Chi Minh City, Vietnam.

- Krejcie, R. V., \& Morgan, D. W. (1970). Determining sample size for research activities. Educational and Psychological Measurement, 30, 607-610. Crossref

- Monshipouri, M., Welch, C. E. \& Kennedy, E. T. (2003). Multinational corporations and the ethics of global responsibility: problems and possibilities. Human Rights Quarterly, 25(4), 965-989. Crossref

- Nilsson, A. \& Westerberg, M. (1997). Business ethics and systems thinking. Journal of Systems Practice, 10(4), 25-32 Crossref

- Nulty, D. D. (2008). The adequacy of response rates to online and paper surveys: What can be done? Assessment \& Evaluation in Higher Education, 33, 301-314. $\underline{\text { Crossref }}$

- Nunnally, J. C. and Bernstein, I. H. (1994). Psychometric theory (3rd ed.), New York: McGraw Hill.

- Nwachukwu, I. (2006) Institutions indulge in tax evasion despite huge profit they make in Nigerian. The Tribune, September, 1, 2006.

- Okereke, C. I. \& Daniel, A. (2010). Staff welfare and productivity in Patani local government council, Delta State Nigeria. Journal of Economics and International Finance, 2(12), 313-320.

- Olaru, S. D. \& Gurgu, E. (2009). Ethics and integrity in multinational companies. Review of International Comparative Management, 10(1), 113-120.

- Patrick, D.L., Burke, L., Gwaltney, C.J., et al, (2011). Content validity — establishing and reporting the evidence in newly developed patient-reported outcomes (PRO) instruments for medical product evaluation: ISPOR PRO good research practices task force report: Part 2-assessing respondent understanding. Value Health. 14:978988. Crossref

- Patterson, M., Warr, P., \& West, M. (2004). Organizational climate and company production: The role of employee affect and employee level. London: Centre for Economic Performance, London School of Economics and Political Science.

- Pattison, S. \& Edgar, A. (2011). Integrity and the moral complexity of professional practice. Nursing Philosophy, 12(2), 94-106. Crossref

- Pettijohn, C. H., Pettijohn, L., \& Taylor, A. J. (2008). Salesperson perceptions of ethical behaviours: Their influence on job satisfaction and turnover intentions. Journal of Business Ethics,78, 547-557. Crossref
- Pirožek, P. \& Drášilová, A. S. (2012). Business ethics in subsidiaries of multinational companies in the Czech Republic.

- Polit, D. F., Beck, C. T., \& Owen, S. V. (2007). Is the CVI an acceptable indicator of content validity? Appraisal and recommendations. Research in nursing \& health, 30(4), 459-67. Crossref

- Polit, D. F., \& Beck, C. T. (2006). The content validity index: Are you sure you know what's being reported? Critique and recommendations. Research in Nursing \& Health, 29, 489497. Crossref

- $\quad$ Robbins, S. P. \& Judge, T. A. (2009). Organizational behavior (13th ed.). Upper Saddle River, NJ: Pearson Education, Inc.

- Runes, D. D. (1964). Dictionary of Philosophy (15th Ed.). New Jersey: Paterson, Littlefield, Adams \& Co.

- Sekaran, U. (2000). Research methods for business: A skill building approach. New York: John Wiley \& Sons, Inc.

- Sims, R.R., \& Brinkmann, J. (2003). Enron ethics (or: Culture matters more than codes). Journal of Business Ethics, 45(3), 243-256. Crossref

- Spence, L., Coles, A. M. \& Harris, L. (2001). The forgotten stakeholder? Ethics and social responsibility in relation to competitors. Business and Society Review, 106 (4), 331-352. Crossref

- Stark, A. (1993). What's wrong with business ethics? Harvard Business Review, 71 (3), 38-48.

- Tabachnick, B. G. \& Fidell, L. S. (2001). Using multivariate statistics (4th edn). New York: HarperCollins.

- Ten, B. R. \& Willmott, H. (2001). Towards a Postdualistic Business Ethics. Journal of Management Studies, 36(6), 879-897.

- Tozer, J. (2012). Leading through leaders: Driving strategy, execution and change. London, UK: KoganPage.

- Treviño, L. K., Brown, M., \& Hartman, L. P. (2003). A qualitative investigation of perceived executive ethical leadership: Perceptions from inside and outside the executive suite. Human Relations, 56, 5-37. Crossref

- Truxillo, D. M., Bauer, T. N., \& Erdogan, B. (2016). Psychology and work: Perspectives on industrial and organizational psychology. New York: Routledge.

- Uddin, M. J., Luva, R. H. \& Hossian, S. M. S. (2013). Impact of organizational culture on employee performance and productivity: A case study of telecommunication sector in Bangladesh. International Journal of Business and Management, 8(2), 63-77.

- Valentine, S., Godkin, L., Fleischman, G. M., \& Kidwell, R. (2011). Corporate ethical values, group creativity, job satisfaction and turnover intention: The impact of work context on work response. Journal of Business Ethics, 98, 353-372. Crossref

- Wu, X. (1999). Business ethical perceptions of business people in east China: An empirical study. Bus. Ethics Quarterly, 9(3), 541-559. Crossref 